\title{
Pedagogical practices of the grade $6 \&$ grade 7 teachers in teaching reading on the blended learning modality
}

Prácticas pedagógicas de los profesores de $6^{\circ}$ y $7^{\circ}$ grado en la enseñanza de lectura en la modalidad blended learning Práticas pedagógicas dos professores do $6^{\circ}$ e $7^{\circ}$ ano no ensino da leitura na modalidade blended learning

Jocoh P. Romero, Ph.D. (C) jocoh.romero@deped.gov.ph Rizal Central Elementary School, Kapatagan, Digos City, Davao del Sur https://orcid.org/0000-0002-0069-1265

Athena Joy Q. Lim, Ph.D. (C) athenajoy.lim@deped.gov.ph Digos City National High School, Digos City, Davao del Sur https://orcid.org/0000-0001-7415-3809

\begin{abstract}
This study dealt with the pedagogical practices of the Grade 6 \& Grade 7 teachers of Digos City National High School and Rizal Central Elementary School from the Schools Division Office of Digos City, Davao del Sur in teaching reading on the blended learning modality. Participants of the study were purposively chosen. Open-ended interview questions related to pedagogical practices were formulated. A qualitative research design, using a phenomenological method on exploring the pedagogical practices of teachers teaching reading in English was utilized. Based on the result of the study, there are three basic components that describe the pedagogical practices of reading teachers which are prereading activities, during reading activities, and post-reading activities. Reading teachers used these activities as they worked to overcome the difficulties of teaching reading during the epidemic. Lack of support, lack of technology, and lack of motivation were the challenges that reading teachers encountered upon teaching reading to Grades 6 and 7 . Finally, collaboration is the leading ingredient of the reading model that directs the actions of the three elements: the parents, teachers, and students. To make the model functional, these elements should collaboratively work. It is hereby recommended that in order to enhance teachers' capacity to teach reading, continuous training may be conducted to supplement teachers' knowledge and capacitate them in teaching reading, teacher-parent dialogue may be conducted to help parents fully understand their roles in the success of their children and the further enhancement of the reading model by conducting research relevant to the subject being studied.
\end{abstract}

Keywords: pedagogical practices, qualitative research, phenomenological method, pre-reading activities, during reading activities, post-reading activities, lack of support, lack of technology, lack of motivation, collaboration

\section{RESUMEN}

Este estudio abordó las prácticas pedagógicas de los docentes de $6^{\circ}$ y $7^{\circ}$ grado en la enseñanza de la lectura en la modalidad semipresencial. Se utilizó un diseño de investigación cualitativo, utilizando un método fenomenológico en la exploración de las prácticas pedagógicas de los profesores que enseñan a leer en inglés. Los participantes del estudio fueron elegidos intencionalmente. Con base en el resultado del estudio, existen tres componentes básicos que describen las prácticas pedagógicas de los profesores de lectura que son las actividades previas a la lectura, durante las actividades lectoras y las actividades posteriores a la lectura. Estas actividades fueron empleadas por maestros de lectura a medida que avanzaban para superar los desafíos de enseñar a leer durante la pandemia. La falta de apoyo, la falta de tecnología y la falta de motivación fueron los desafíos que encontraron los maestros de lectura al enseñar lectura a los grados 6 y 7. Finalmente, la colaboración es el ingrediente principal del modelo de lectura que dirige las acciones de los tres elementos: los padres, maestros y estudiantes. Para que el modelo sea funcional, estos elementos deben trabajar en colaboración.

Palabras clave: prácticas pedagógicas, investigación cualitativa, método fenomenológico, actividades previas a la lectura, actividades durante la lectura, actividades posteriores a la lectura, falta de apoyo, falta de tecnología, falta de motivación, colaboración

\section{RESUMO}

Este estudo tratou das práticas pedagógicas dos professores do $6^{\circ}$ e $7^{\circ}$ ano no ensino da leitura na modalidade de ensino híbrido. Foi utilizado um desenho de pesquisa qualitativa, utilizando um método fenomenológico para explorar as 
práticas pedagógicas de professores que ensinam leitura em inglês. Os participantes do estudo foram escolhidos propositalmente. Com base no resultado do estudo, existem três componentes básicos que descrevem as práticas pedagógicas dos professores de leitura que são as atividades de pré-leitura, durante as atividades de leitura e as atividades de pós-leitura. Essas atividades foram empregadas por professores de leitura à medida que progrediam na superação dos desafios do ensino da leitura durante a pandemia. Falta de apoio, falta de tecnologia e falta de motivação foram os desafios que os professores de leitura encontraram ao ensinar leitura para os $6^{\circ}$ e $7^{\circ}$ anos. Finalmente, a colaboração é o ingrediente principal do modelo de leitura que direciona as ações dos três elementos: os pais , professores e alunos. Para tornar o modelo funcional, esses elementos devem funcionar de forma colaborativa.

Palavras-chave: práticas pedagógicas, pesquisa qualitativa, método fenomenológico, atividades de pré-leitura, durante as atividades de leitura, atividades de pós-leitura, falta de apoio, falta de tecnologia, falta de motivação, colaboração

\section{INTRODUCTION}

Reading is one of the most important macro skills that need to be acquired by the learners to be able to decode a volume of information that they will be encountering as they progress from one grade level to another. One must learn to read and comprehend what one is reading. However, despite the teacher's effort in making every learner able to read independently, several elementary and high school learners stay behind other learners in terms of their reading comprehension skills. This phenomenon has posed alarm not only among educators but also among teachers as learning the core subjects and essential competencies becomes a major academic problem due to the inability to read.

The Organization for Economic Co-operation and Development (OECD) revealed world rankings on students' performance in mathematics, science, and reading based on the 2018 Program for International Student Assessment (PISA) wherein it was interpreted that over 80\% of students in the Philippines did not reach a minimum level of proficiency in reading, which is one of the largest shares of low performers amongst all PISA-participating countries and economies (PISA, 2018).

The task of improving learners reading comprehension skills through teaching reading has become even more challenging with the advent of the COVID-19 pandemic which causes a tremendous change in the country's education system. Just in a matter of months, the pandemic has affected the daily routines of the learners and the teaching-learning process itself resulting in the closure of schools and restrictions of movements (Tidey, 2020).

At this time of the global pandemic, $100 \%$ of the learners are at home and opt for blended modality, and how are they going to cope with the global education obligation is a big challenge. In Digos City Division, both elementary and secondary schools embarked on the development of the Basic Education-Learning Continuity Plan (BE-LCP) to enable learners of basic education to continue learning, and for teachers to be able to deliver instructions in a safe work and learning environment amidst the threat of COVID-19 (DepEd, 2020). The role of the teacher is in teaching reading to help increase the level of reading comprehension of the learners even if they are learning from home.

This situation urges the researchers to conduct a study on the pedagogical practices of the English teachers in teaching reading to gain information on the different strategies that they have used amidst the country's current educational system.

\section{Statement of the Problem}

The main objective of this qualitative study is to explore the pedagogical practices of the Grade 6 and Grade 7 English teachers in teaching reading on Blended Learning Modality in Digos City National High School and Rizal Central Elementary School from the Schools Division Office of Digos City, Davao del Sur.

Specifically, this study aims to:

1. Determine the pedagogical practices of teachers in teaching reading, 
2. Identify the challenges encountered by teachers in teaching reading, and

3. Develop a reading model relevant to the current situation of the learning modality.

\section{Scope and Limitations}

The study focused on the pedagogical practices of English teachers in teaching reading on the Blended Learning Modality. Merely, this study was limited to selected English teachers of Digos City National High School and Rizal Central Elementary School of the Schools Division Office of Digos City, Davao del Sur. This study was conducted in October 2021.

\section{Significance of the Study} following:

The relevant information generated from this qualitative research may be used by the

Department of Education. The result of the study may serve as a basis to consider in developing a teaching reading model that would facilitate teaching reading effectively in the context of the teachers and the learners at home.

School Heads. The responsibility and accountability in schools strongly lie on the school heads for they administer, manage, and supervise different programs, projects, and activities, especially in English subjects. In this sense, the results of this study could provide relevant information to the school heads regarding the possible coping mechanisms of the English teachers in teaching reading.

English teachers. Being the facilitator of learning, the teacher may be able to relate to the pedagogical practices of the teachers in teaching reading. The results of this study could give them a wide array of perspectives on what are the possible mechanisms that may be effectively used in bringing better reading ability to the learners amidst the pandemic.

Parents. The findings would help parents to realize that their role in their children's education is very important; that the need to reach out to their children and help them cope with the pressure when learning to read especially in times of pandemic.

Future Researchers. This study is of great help for future researchers who would want to study in-depth using qualitative research. This could serve as a reference for their investigation.

\section{THEORETICAL FOUNDATION}

Reading is an intricate process involving word recognition, vocabulary, and comprehension, and learning to read has been a very important goal for us to gain the world of knowledge and opportunities. The need to learn reading has resulted in the fundamentals of these major reading theories such as behaviorism, cognitivism, and constructivism which have also been the basis of these three basic theories: bottom-up, top-down, and interactive.

This study is anchored on Goodman's top-down model of comprehension (Grabe, 2009). It presumes that the reading process is guided not by decoding of letters and parsing of syntax and semantics, but by a reader's background knowledge and expectations. This means that readers construct meaning from what $\mathrm{s} /$ he already knows and expects from the text. The model also ascribes great power to the ability to guess and anticipate. The model opposes the idea that reading involves precise and sequential parsing of letters and words. Rather, for Goodman, reading entails identifying and parsing only a minimal number of letters and words, just enough to produce accurate guesses at text meaning. According to the model, good readers would skip over several portions of the text. Thus, in this model, a good reader relies on context cues, and poor readers rely on a close letter and word identification.

The set of pedagogical practices that followed from Goodman's model is called Whole Language. This is an approach to the teaching of reading that, in its most extreme form, advocates 
that reading should not be taught at all (Pressley, 2004). Instead, learners should simply be given lots of opportunities to interact with the text. That is, learners, learn to read by reading a lot. In less extreme forms, a Whole Language approach involves giving learners background knowledge on the topic of a text, encouraging learners to predict the meaning of a text using context cues such as titles and sub-titles, images, and so on; it also involves teaching strategies to guess the meaning of new words (Presley, 2004). The Whole-Language movement has been the single most influential force on EFL reading pedagogy (Grabe, 2009), which may explain while the latter makes extensive use of guessing from context and providing background knowledge.

Furthermore, in support of the main model above, the interactive-compensatory model of comprehension (Stanovich, 2000 [1980], 2000 [1984]) does explain the role of top-down and bottom-up processing. The model posits that comprehension includes processes operating at many levels, e.g., letter recognition, word recognition, phrase recognition, and so on. Then, the model makes two assumptions. First, there is the assumption that "recognition of meaning takes place via the simultaneous amalgamation of information from many different knowledge sources" (2000 [1980], p. 49). Some of these sources can be higher-level ones, like topic knowledge, while others can be lower-level ones, like syntactic or orthographic knowledge. Second, there is the assumption that "deficiencies at any level in the processing hierarchy can be compensated for by greater use of information from other levels irrespective of the level of the deficient process" (id.). That is, failure to understand an idea using previous knowledge, for example, can trigger the application of careful syntactic and semantic analysis of the corresponding text segment to repair such failure. The model predicts that both good and poor readers may use both bottom-up and top-down processes at different times during reading based on moment-to-moment needs and difficulties.

Figure 1 presents the theoretical framework supporting the study. The framework shows that the learners are the center of the teaching of reading endeavors. However, the teachers play vital roles in this process. Teachers need to acknowledge that learners are diverse and have different knowledge backgrounds. Therefore, they differ in ascribing meaning to the same text. Because the learners are varied, their reading comprehension level also differs depending on their semantic, syntactic, orthographic, and lexical information.

The figure presents the top-down reading theory as explained by Goodman. When the learners approach the text, their comprehension is dependent on what they have learned in the past or their background knowledge and their anticipation. The figure below presents how learners obtain comprehension when reading the text. Upon approaching the text, learners unfold relevant experiences and possibilities from the past to understand it, thus, comprehension is achieved.

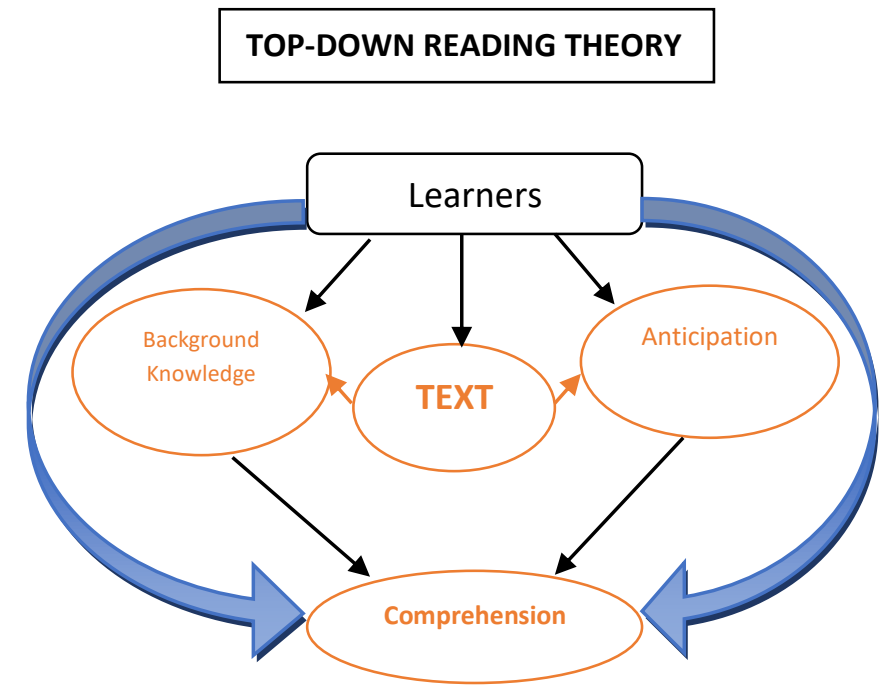

Figure 1. Theoretical Framework 


\section{Conceptual Framework}

This study was conducted to find out what are the pedagogical practices of the reading teachers. There are several reading strategies frequently used by English reading teachers during this challenging time of the pandemic. This study sought to uncover how these reading teachers employed these reading strategies to improve the reading ability of the students even in this time of the pandemic. English reading teachers were asked what strategies they used to teach reading and how they employed such strategies. Because this is the time of the pandemic, there is a certain teaching model that was developed, and this is presented in this study.

Figure 2 demonstrates the conceptual framework of the study. Teachers were interviewed about what pedagogical practices they employed in teaching reading. In teaching reading, teachers may demonstrate varied reading strategies during this time of the pandemic. Reading Strategies is the first phase the study wanted to find out. After knowing the strategies, how teachers employed such teaching of reading strategies is revealed thus, the Process in the second phase. The process is the implementation stage that demonstrates activities teachers conducted while engaging with their learners in teaching reading while employing the reading strategies. From this information gathered about teaching strategies and processes, the Teaching of Reading Model can be designed in teaching reading in this time of the pandemic. As an output of this study, the teaching of the reading model is developed. As presented in the framework below, the reading strategies are documented, then the process was analyzed, then the teaching of the reading model is developed.

\section{Teaching Reading Development Process}

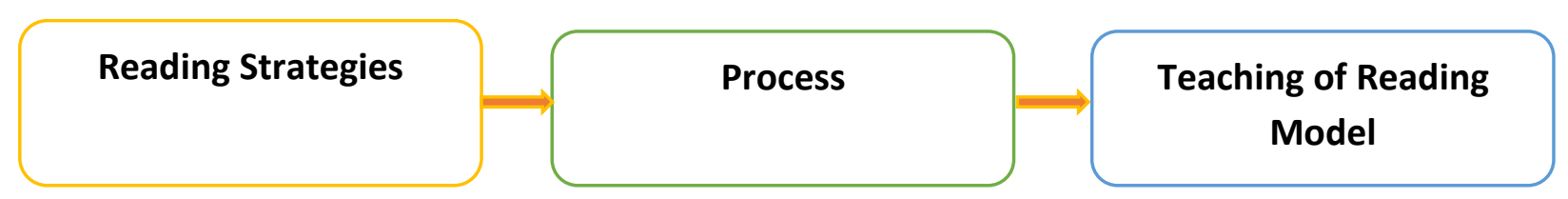

Figure 2. The Conceptual Framework of the Study

\section{Definition of Terms} defined:

For clarity and precision, the following terms are operationally and technically

BE-LCP- means Basic Education continuity plan. A package of education interventions that will respond to basic education challenges brought about by COVID-19.

Blended Learning Modality-. refers to a kind of instruction that includes two or more of the following methods: face-to-face instruction, online instruction, modular instruction, radio broadcast, etc.

Distance Learning- a form of education that is used this time of pandemic which requires physical separation of teachers and students during instruction that used various types of technologies in establishing communication for meaningful learning experiences.

English teachers- English teachers refer to the subject and participants of the study who use pedagogy in teaching reading.

Group Chat- Group chat refers to a group in the messenger formed by teachers together with their students used to maintain teacher-student communication.

Instant messages- Instant messages are a method of communication using a mobile phone or a computer allowing messages to transmit in real-time.

Messenger- Messenger refers to an online application used to communicate using a mobile phone or a computer through one's Facebook account. 
Online Learning- Online learning is a form of teaching and learning approach conducted without requiring face-to-face presence using the internet connection to communicate.

Pedagogical practices- Pedagogical refers to the strategies and techniques applied by teachers in teaching reading.

Reading Comprehension Skills- Reading comprehension skills in this study refer to the ability of learners to process text, understand its meaning, and integrate meaning with what the reader already knows.

\section{METHODOLOGICAL PROCEDURES}

This chapter presents the design, respondents and sampling method, setting, instrument, data gathering procedures, and ethical consideration of the study.

\section{Research Design}

This study employed a qualitative research design, using a phenomenological method on exploring the pedagogical practices of teachers teaching reading in English. According to Wise (2011), exploratory qualitative study is the most common type of qualitative research. It is a kind of study that aims to create a comprehensive, largely narrative description of a social or cultural phenomenon in order to inform the researcher's understanding of it. This concept aimed to find answers to issues by following a predetermined set of procedures to answer them and when collecting evidence.

Specifically, this study used a qualitative phenomenological approach which describes the meaning for several individuals of their lived experiences of a concept or phenomenon (Creswell, 2008). According to Christensen, Johnson, and Turner (2010) cited by Simon and Goes (2013), the primary objective of a phenomenological study is to explicate the meaning, structure, and essence of the lived experiences of a person, or a group of people, around a specific phenomenon.

Phenomenology was used in this study because, as English teachers, the researchers were immersed in teaching reading and were able to observe the aforementioned phenomenon. With this method, the researchers were able to explore the lived experiences of other reading teachers to fully grasp the essence of what strategies do teachers used in teaching reading, how the teachers teach reading, and what teaching of the reading model can be derived from being exhibited during this time of the pandemic.

In-depth interviews were done as we interviewed the participants. According to Boyce and Neale (2006), in-depth interviewing is a qualitative research technique that involves conducting intensive individual interviews with a small number of respondents to explore their perspectives on a particular idea, program, or situation.

First, the researchers wrote research questions that explore the meaning of lived experiences for individuals and ask individuals to describe these experiences. The researchers collected data, typically via in-depth interviews, from individuals who have experienced the phenomenon under investigation. Next, the data analysis involved horizontalization, extracting significant statements from transcribed interviews. The researchers incorporated their meanings of the experience here. Finally, the report was written such that readers understand better the essential, invariant structure of the experience of the essence of the experience.

The researchers' goal was to gain a better understanding of the pedagogical practices of the teachers in teaching reading during the blended learning modality.

\section{Respondents and Sampling}

As recommended by Creswell (2013), a minimum of three (3) to a maximum of fifteen (15) people should participate in phenomenological research in a varied group. Purposive sampling was 
used to choose participants for this phenomenological investigation. Purposive sampling is a technique used by qualitative researchers to ensure that a sample of participants offers a large amount of data about a phenomenon (Palinkas et al., 2015). Purposive sampling was used to identify participants to pick crucial and specific persons who could supply the most information to answer the research questions.

The research participants of this study were three Grade 7 English Teachers of Digos City National High School and one Grade 6 English Teacher of Rizal Central Elementary School.

\section{Research Setting}

The venues of the research were Digos City National High School, Digos City, and Rizal Central Elementary School, Kapatagan, Digos City. Due to the pandemic, the researchers utilized social media platforms such as messenger, google meet or zoom to unearth the pedagogical practices and challenges in teaching reading by the English teachers during this time of the pandemic.

\section{Research Instrument}

Interview guide questions were used in this study to describe the pedagogical practices in teaching reading in English during the pandemic. These interview guide questions were subjected for validation and enhancement by the experts and further the panel committee.

1. What are the pedagogical practices of teachers in teaching reading?

a. How do you teach your students reading?

b. What are the strategies you used in teaching reading?

2. What are the challenges encountered by teachers in teaching reading?

a. How was your class going during the pandemic?

b. What are problems you encountered during the conduct of classes during the pandemic?

3. What insights can help develop a reading model relevant to the current situation of learning modality.

a. How do you resolve the problems during the conduct of classes during the pandemic?

b. What reading model can be designed in teaching reading during the pandemic?

\section{Data Gathering Procedure}

After the enhancement of the research proposal as recommended by the Qualitative Research and Data Management subject professor, the researchers approached the Senior Education Program Supervisor of the Schools Division Office of Digos City to request or ask for endorsement together with the permission to start the research. Open-ended interview questions related to pedagogical practices were formulated. In-depth interviews were conducted from the three Grade 7 English teachers of Digos City National High School and two English Teachers of Rizal Central Elementary School.

An audio recorder was used to capture significant statements from the participants during the interview. After each interview, the researchers transcribed the recordings verbatim.

\section{Ethical Consideration}

The conduct of research must uphold ethical consideration to ensure that no rights of the informants were violated in the course of the study.

The observance of ethics in the conduct of the study was manifested in the form of following protocols and orientation. The researcher met the respondents of the study after the approval of the conduct of the research. In the meeting, the researcher gave orientation to the respondents regarding the purpose of the research including the roles they would perform as part of the study. The researcher also informed the respondents that their participation was voluntary and assured them that their non-participation would not have any effect on their performance. All informants were asked to sign the Consent Form indicating their interest to be part of the study. 
The researcher informed the respondents about the practiced value of confidentiality; the recorded information in the data gathering procedure was kept and was not made accessible to anybody. There were no names written in the questionnaire. To truly uphold privacy and secrecy in the process, the researcher did not show anybody the survey tool which the respondents used. In the same manner, the researcher prohibited the sharing of information about the respondents to ensure anonymity. Similarly, there was no information shared attributed to the respondents to ensure secrecy.

\section{RESULTS AND DISCUSSION}

The study was conducted to discover the pedagogical practices of the Grade $6 \& 7$ teachers in teaching reading on the blended learning modality and answered the following questions: What are the pedagogical practices of teachers in teaching reading? What are the challenges encountered by teachers in teaching reading? And What insights can help develop in reading model relevant to the current situation of learning modality?

\section{The Pedagogical Practices of Teachers in Teaching Reading}

The researchers, being the experienced reading teachers had been immersed in the field encountering varied students with varied reading abilities. Based on the conducted in-depth interviews, no teacher employed teaching of reading strategy without having first the assessment of the reading level of their reading students. Before teachers start teaching reading, they should first learn the level their students are in through their Phil-IRI result. Phil-IRI or the Philippine Informal Reading Inventory is a tool used to measure and describe the reading performance of students (Llego, 2018). Then, teachers will categorize students based on their level of reading ability to be able to organize their teaching schedules and materials. These are the common activities teachers do preliminary to employing teaching methods and strategies.

As the informants were asked their pedagogical practices, the process of teaching reading emerged. The figure below presents the pedagogical practices of teachers in teaching reading as described by the informants.

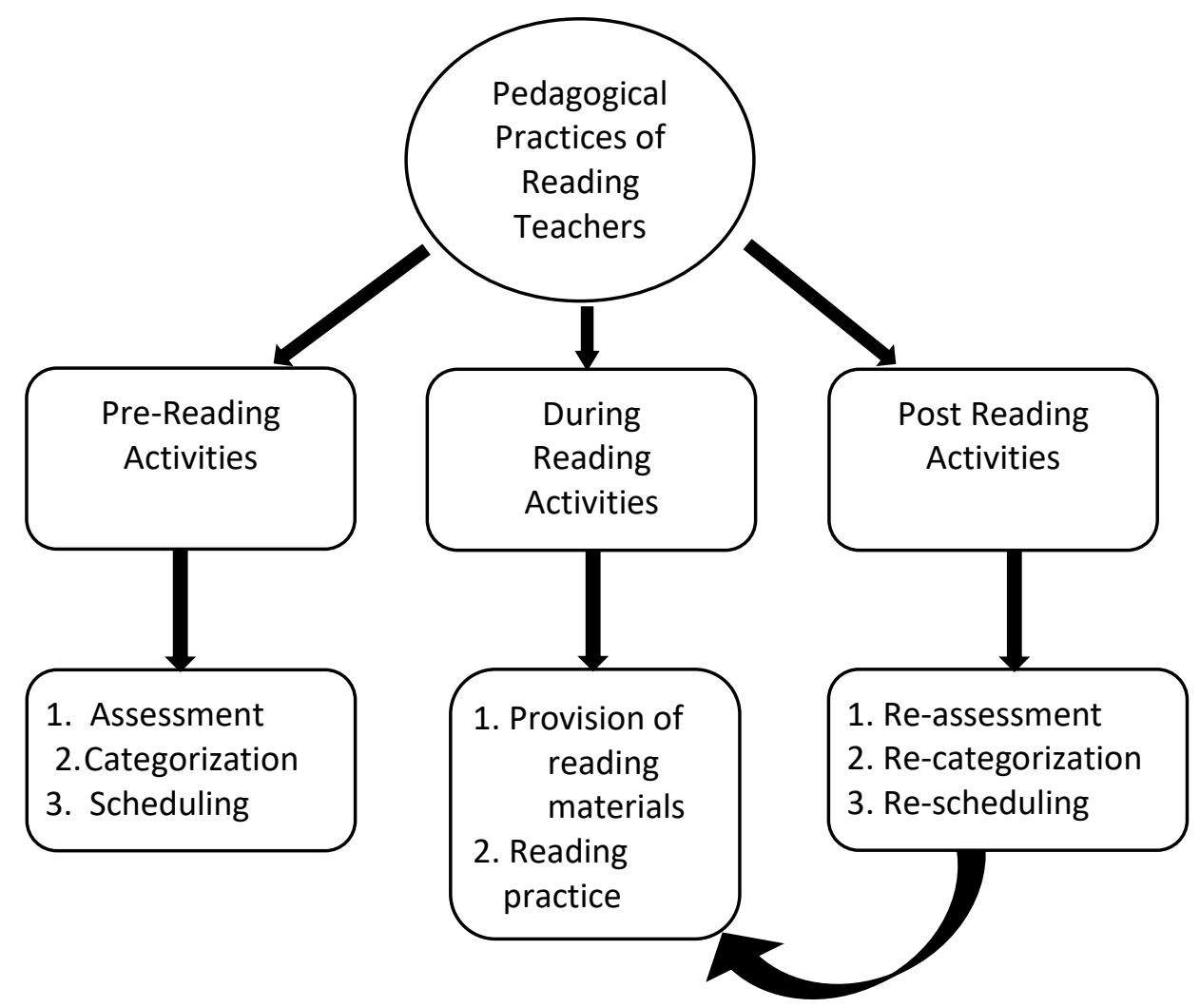


Figure 3. The Pedagogical Practices of Reading Teachers

In figure 3, three basic components describe the pedagogical practices of reading teachers as revealed by the informants of this study. These are the pre-reading activities, during reading activities, and post-reading activities. These three phases were chronologically employed by reading teachers as they progressed towards overcoming the challenges of teaching reading during the pandemic.

Pre-reading activities. During this phase, three activities were identified by the reading teachers. First, assessment; second, categorization; and third, scheduling. Teachers assessed the level of their students. The assessment was done through their recorded evaluation as described in Phil-IRI. "It was a difficult task to conduct Phil-IRI during the pandemic", according to the informants but, there was always a way for those who have the will. After knowing the level of students' reading ability, the teacher categorized students by groups identifying them based on their level. Three levels can be described using the Phi-IRI, frustration, instructional, and independent levels. Those students who belonged to the frustration level were grouped and given remedial reading instruction as they needed more focus and attention to succeed and proceed to the next grade level. Then, teachers set their schedule on when they make their remedial reading instruction.

During reading activities. This phase presents the processes of teaching reading. In this phase, teachers provide reading materials and do the reading practice. The informants enumerated the activities conducted during the reading remediation sessions. Teachers provided reading materials based on the level of the students starting with basic sight words, then phrases, short stories, then giving comprehension questions after each session. The conduct of the remedial reading instruction was not the same as before the pandemic where teachers and students can meet and interact with each other face to face. Currently, teachers use online platforms such as FB Messenger, Google Meet, or cellular phone whichever be available and convenient for students. Teachers conduct a video call to students when they have remedial reading instruction. More often, teachers created a group chat in Facebook Messenger to be readily available to both students' and teachers' concerns. Teachers always ensure that students' preference and comfort is addressed to establish closer connection and trust. For some students who have no internet connectivity or gadget to use for online instruction, the teachers conducted limited face-to-face with their students.

In the conduct of limited face-to-face, teachers asked first the parents' or guardians' approval to do a home visit to students involved in the remediation. Minimum health protocol was always observed such as the washing of hands with alcohol, wearing of facemask, and proper distancing. When teachers have already set the schedule for a home visit or online remediation, the lessons shall start. The first lesson that was introduced was on the basic sight words if students were already familiar with the sounds of the alphabet. But if the students did not master yet the sounds of the alphabet, the teachers had to start the sounding before introducing the basic sight words. When students are already familiar with the basic sight words, the teacher then introduced phrases, then simple sentences, to paragraphs, and then to short stories. Teachers ensured that the text provided in their short story was appropriate to the level of their students and could help activate prior knowledge of the students. In the conduct of online reading remediation, the teachers started the class with netiquette, informing students what to do and not to do during online reading remedial classes. As part of the checking of attendance, teachers called each student one by one and asked how their day was going to establish rapport with them. On the other hand, in the limited face-toface instruction, the teacher started with preliminary greetings with the parents asking them how their child is doing until the child is settled in the venue of their remedial reading instruction. The class properly commonly started with asking them what they recall of the past lesson then slowly progressed to their current topics.

Post-reading activities. The last phase of the pedagogical practices of teachers teaching reading was where the cyclical phase continues to happen until the students reached the appropriate reading level. There was re-assessment, re-categorization, and re-scheduling in the post-reading 
activities. These three components of the post-reading activities were just similar to the first phase only that, students' progress was now evident and text for practice was at a higher level.

Reading is a skill that involves the ability to interpret or decode printed symbols. According to Okwilagwe (1988), learning to read starts from mastering the alphabet of a language. The skill of interpreting or decoding the alphabet of the language is valuable to be taught to students learning to read. Word identification needs to be developed first when teaching reading. "A child cannot understand what he cannot decode, but what he decodes is meaningless unless he can understand it" (Moats, 1999). Thus, reading comprehension begins from interpreting and decoding symbols.

\section{The Challenges Encountered by Teachers in Teaching Reading}

The pandemic has brought drastic changes in the educational system that affects everyone. Teachers and students are confronted with some challenges and fought all odds to continue life in education.

Teachers clamored on the many tasks and paper works they needed to accomplish to improve the quality of education despite the pandemic. But in the real sense, they thought that achieving the quality all has hoped for, is surreal for a country less equipped and prepared.

Whatever the phenomenon though, Filipinos are known for resiliency. Teachers were sent to training to learn how to conduct online classes. They were also taught how to design instructional materials using new technologies. Radio and TV programs were also designed to become educational platforms and teachers were trained to use them. They become actresses in their classrooms. However, challenges are always present.

When reading teachers were asked about the challenges, they encountered upon teaching reading to Grades 6 and 7, they said a lot. The figure below presents the challenges the reading teachers encountered while teaching reading. Their responses revolved around the "lack of something", the lack of support, lack of technology, and lack of motivation. Looking into the figure the challenges are all external involving parents, students, and technical support.

Lack of support. The teachers expressed that there are parents that did not come to school to get their child or children's module on the scheduled date. When modules are not taken by parents on the scheduled date, there is a possibility that the return of the module will be delayed. The tendency is, they will be delayed in all the submissions of requirements. And because there are deadlines to meet, most modules will be returned without completion of the required tasks. This is considered as a lack of parents' support to their children who need parents' attention. Another disturbing challenge about lack of support is the lack of assistance at home. Some parents can afford to get their children's modules on time but could not assist their children's learning needs at home. As a result, the modules are still returned unanswered.

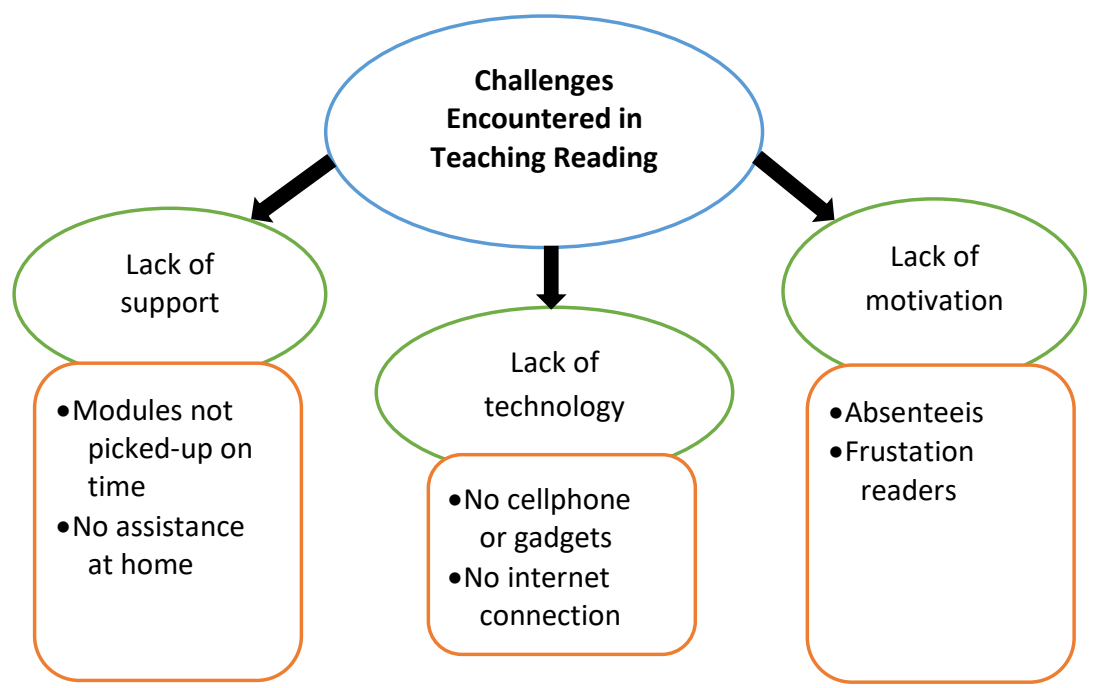


Figure 4. The Challenges Encountered in Teaching Reading.

Lack of technology. This lack of technology is a persisting challenge in the acquisition of knowledge during this pandemic. So much so with the students who have difficulties in reading. Teachers complained that there are students who have no gadgets like mobile phones, smartphones, laptops, or desktops. Making things worst, many have no stable internet connection or no internet connection at all. For the reading teachers, it is too difficult for them not to be able to communicate with their students when they teach. So, some strategies were conducted with those who have no gadgets or internet connection at home or in their village.

Lack of motivation. Of all the challenges, this is considered the most disappointing because there is no effect on those who do not want to be helped. Some students were not interested to join the reading class for the reasons of "lack". Because some of them lack parental support and gadget, their interest to learn waivered. They did not attend class as required and because of this, they remained at the frustration level. Some students were also affected knowing that they are at the frustration level, and this too magnifies their lack of interest and motivation.

\section{Reading Model for the New Normal Learning Modality}

The pandemic has changed the lifeways of many people and the educational system too. Teachers and students are both forced to embark into a system of the new normal trying to fit in. Insights from the responses of the informants were collated and analyzed which presents a reading model for the new normal learning modality. This reading model for the new normal learning modality was deemed to address the challenges mentioned above. The reading model begins with the strategy of collaboration among teachers, students, and parents. The teacher is numbered "1" as it is where collaboration should imamate. As the facilitators of learning, teachers are given pedagogical tasks so, they directly communicate and collaborate with their students. Because of the pandemic, students need some assistance they will ask from their parents as parents are the immediate supporter of students. So, the second collaborators are the students. Collaboration happens then between students and their parents. The next collaboration is between parents and the teachers. Parents will relay their issues and concerns of their students to the teachers. During the collaboration, negotiations happen among them. So, inside the circle of direct collaboration represented by the curves in the model, arrows are pointing at each other, which represents that in the negotiation process, the collaboration can be among teachers-students-parents; parents-studentsteachers; or students-teachers-parents all together.

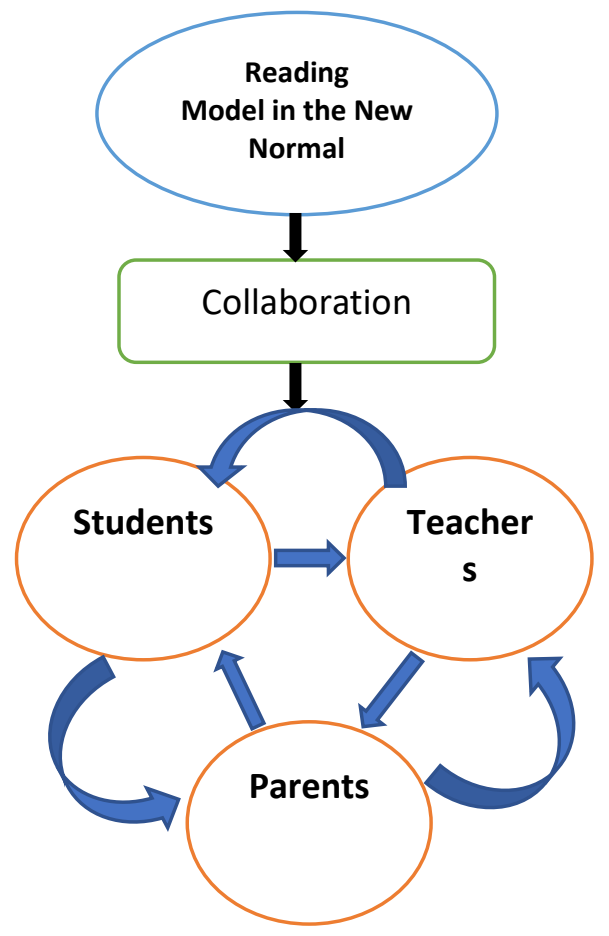


Figure 5. The Reading Model of the New Normal

Figure 5 presents a reading model of collaboration. In this model, collaboration is emphasized as the leading ingredient of the model which directs the actions of the parents, teachers, and students. Without collaboration, the three elements in the model cannot function.

Parents. In the reading model, parents play a very crucial role in the success of their children. When parents lack the support their children need, this will lead to the loss of students' motivation to learn. Parents need to maintain and strengthen their connection with the teachers especially so that students are learning in the new normal condition, where they are alienated from their classmates and friends in school because of restrictions to conduct face to face-to-face classes.

Students. Students should be understood that they are suffering because of the loss of faceto-face classes. They are currently adjusting to this loss because being away from friends and classmates in school to the confinement at home is traumatic. Students are dealing with their psychological pain while adjusting to the new learning modality. This is not easy. Thus, parents have to look closely at their children and ensure that everything is alright. That, it is alright to stay at home because it is safer there than somewhere outside. Parents have to establish trust with their children, this is why their support for their children's education is truly important.

Teachers. Teachers are to become heroes during this time of the pandemic. With all the training they obtain, they are expected to perform better in their classes. In teaching reading during this blended learning modality, teachers should explore better possibilities to make learning interesting for young learners. Students are already bored at home. Having a boring reading class is already torture. With this, teachers should collaborate with parents by helping them teach their students when at home.

\section{Summary of Findings}

This study focused on exploring the pedagogical practices of the teachers teaching reading in the blended learning modality. The qualitative method is used in the study employing phenomenology in gathering and analyzing data. This study was conducted among Grades 6 and 7 teachers of reading in selected schools of Davao del Sur. The study sought to determine the pedagogical practices of teachers in teaching reading; identify the challenges encountered by teachers in teaching reading and draw insights that can help develop a reading model relevant to the current situation of learning modality.

Three basic components describe the pedagogical practices of reading teachers as revealed by the informants of this study. These three components are the pre-reading activities, during reading activities, and post-reading activities. These three phases were chronologically employed by reading teachers as they progressed towards overcoming the challenges of teaching reading during the pandemic. Teachers were asked about the challenges they encountered upon teaching reading to Grades 6 and 7. Their challenges revolved around the "lack of something", the lack of support, lack of technology, and lack of motivation. The reading model for the new normal modality emphasized collaboration. Collaboration is the leading ingredient of the model which directs the actions of the three elements: the parents, teachers, and students. Without collaboration, the three elements in the model cannot function.

\section{CONCLUSION}

This study is anchored on Goodman's top-down model of comprehension (Grabe, 2009). Based on the result of the study, the three basic components that describe the pedagogical practices of reading teachers are the pre-reading activities, during reading activities, and post-reading activities. These activities were employed by reading teachers as they progressed towards overcoming the challenges of teaching reading during the pandemic. The challenges reading teachers encountered upon teaching reading to Grades 6 and 7 were the lack of support, lack of 
technology, and lack of motivation. Finally, collaboration is the leading ingredient of the reading model that directs the actions of the three elements: the parents, teachers, and students. Without collaboration, the three elements in the model cannot function.

\section{Recommendations}

The entirety of this qualitative research has provided essential and useful data which will serve as an eye opener in the field to give importance to adapt to the new reading model in the new normal education.

With the result and findings gleaned from the study, the following recommendations are formulated to enhance teachers' capacity to teach reading.

1. Continuous training may be conducted to supplement teachers' knowledge and capacitate them in teaching reading.

2. The challenges revealed by the reading teachers were valid. Teacher-parent dialogue may be conducted to help parents fully understand their roles in the success of their children.

3. The designed model can still be enhanced. Further research may be conducted relevant to the subject being studied.

This research provides relevant and essential information for the schools to provide make use of the new reading model to be able to cope up with the challenges brought about by the unprecedented COVID-19 pandemic.

The future researchers may use this new reading model and delve on its level of effectiveness among reading teachers in the school.

\section{REFERENCES}

Creswell, J. W. (2013). Research Design: Qualitative, Quantitative, And Mix Method Approaches. Sage Publishing Inc.

Boyce, C. \& Neale, P. (2006). CONDUCTING IN-DEPTH INTERVIEWS: A Guide for Designing and ... Retrieved October 25, 2016, from http://compositionawebb.pbworks.com/f/conducting in-depth interviews.pdf

DepED. (2020). Learning Opportunities Shall be Available the Basic Education Learning Continuity Plan in the Time of COVID-19. https://www.deped.gov.ph/wpcontent/uploads/2020/07/DepEd_LCP_July3.pdf

Grabe, W. (2009). Reading in a second language: Moving from theory to practice. Cambridge: Cambridge University Press

Llego, M. A. (2018). 2018 Updated Phil-IRI Manual. From TEACHERPH: https://www.teacherph.com/phil-iri-manual-2018/\#: :text=THE\%20PHIL\%2DIRI,What $\% 20$ is \%20the\%20Phil\%2DIRI\%3F,determine\%20a\%20student's\%20reading\%20level

Moats, L. C. (1999). Teaching Reading Is Rocket Science: What Expert Teachers of Reading Should Know and be Able to Do. Washington, DC: National Inst. of Child Health and Human Development (NIH), Bethesda, MD.

Palinkas, L. A., Horwitz, S. M., Green, C. A., Wisdom, J. P., Duan, N., \& Hoagwood, K. (2015). Purposeful sampling for qualitative data collection and analysis in mixed method implementation research. Administration and Policy in Mental Health and Mental Health Services Research, 42(5), 533-544. https://www.ncbi.nlm.nih.gov/pmc/articles/PMC4012002/

PISA. (2018). file:///D:/Downloads/PISA2018_CN_PHL.pdf 
Pressley, M. (2004). The need for research on secondary literacy education. In T. Jetton \& J. Dole (Eds.) Adolescent literacy research and practice (p. 415-432). New York: Guilford Press.

Simon, M. K., \& Goes, J. (2013). What is Phenomenological Research? Retrieved October 25, 2016,http://dissertationrecipes.com/wp-content/uploads/2011/04/Phenomenological-Research.pdf

Stanovich, K. (1980). Toward an interactive-compensatory model of individual differences in the development of reading fluency. Reading research quarterly, 21, 360-407.

Tidey, C. (2020). COVID-19: Children at heightened risk of abuse, neglect, exploitation, and violence amidst intensifying containment measures. UNICEF. https://www.unicef.org/pressreleases/unicef-issues-record-us64-billion-emergency-funding-appeal-reach-more-190-million

Wise, S. E. (2011). Difference between Qualitative Research vs. Quantitative Research.

Retrieved October 25, 2016, from http://www.snapsurveys.com/blog/what-is-the-difference-betweenqualitative-research-and-quantitative-research/

\section{Appendix A}

\section{Grand Tour Questions}

1. What are the pedagogical practices of teachers in teaching reading?

a. How do you teach your students reading?

b. What are the strategies you used in teaching reading?

2 What are the challenges encountered by teachers in teaching reading?

a. How was your class going during the pandemic?

b. What are problems you encountered during the conduct of classes during the pandemic?

3. What insights can help develop a reading model relevant to the current situation

of learning modality.

a. How do you resolve the problems during the conduct of classes during the pandemic?

b. What reading model can be designed in teaching reading during the pandemic? 